\title{
The Three Waves of Spiritual Renewal of the Pentecostal-Charismatic Movement
}

\author{
EMIL BARTOș*
}

\begin{abstract}
The study focuses on the historical dogmatical analysis of the three waves of spiritual renewal which started in the early twentieth century and affected most Christian denominations by focusing on the manifestation of the spiritual gifts. The author will identify the major historical dogmatical influences of the Pentecostal-Charismatic movement, the characteristics and the leaders of the movement, as well as the directions of development on the personal and on the community level.
\end{abstract}

Keywords: Pentecostalism, Charismatism, Neo-Charismatism, spiritual gifts, baptism with the Holy Spirit, speaking in tongues

Undoubtedly, the most important Christian spiritual movement of the last decades (some would say of the last century) is the Pentecostal-Charismatic movement. The current estimates show that the movement has raised over half a billion faithful Christians from all the major Christian denominations, most of them located in the southern hemisphere (South America, Africa and Asia). ${ }^{1}$ Pentecostals derive their name from Pentecost (Pentecost in Greek) - the Descent of the Holy Spirit or the birth of the Church which was marked by the manifestations of the miraculous spiritual gifts (speaking in tongues, prophecies, healings). Pentecostals and Charismatics do not think Pentecost is repeatable, but they think that the mighty spiritual manifestations that have accompanied the event are repeatable and desirable for all the Christians throughout the Church history.

Evidence of the special manifestations of the Spirit is spread throughout the entire history of Christianity. Even though this evidence is sporadic and sometimes there are inconsistencies, it is present as realities historically written. The first Pentecostal churches emerged in the early twentieth century

\footnotetext{
* Emil Bartoș, Reader PhD at the Faculty of Baptist Theology, University of Bucharest. Contact details: Str. Berzei 29, 010521, Bucharest, Romania; e-mail: emilbartos@yahoo.com. 1 The Pentecostal theologian Amos Yong estimated that at the beginning of the third millennium, there were two billion Christians of whom 65 million were Pentecostals, 175 million were Charismatics and 295 million were Neo-Charismatics. If we take into account the growth rate in just two decades, perhaps $10 \%$ of the world population, i.e. one third of all Christians could be Charismatics. Amos Yong, The Spirit Poured Out on All Flesh. Pentecostalism and the Possibility of Global Theology, Grand Rapids 2005, p. 19.
} 
in the United States but the local churches which have already contained the word "Pentecostal" in their names have existed since the second half of the nineteenth century ${ }^{2}$. Half a century later the Pentecostal movement grew significantly in almost all the continents. After the Second World War, the first charismatic groups appeared (from the Greek charisma which means "divine gift") organized outside the classical Pentecostal churches, without delimitating from the denominations they had belonged to. Although they shared the doctrine of baptism in the Holy Spirit with the Pentecostals, the Charismatics were held separately from the Pentecostal churches, preferring the nondenominational and the nonconformist forms. The two religious currents have been preserved to this day, being separated from the organizational, theological and practical point of view.

The Pentecostal-Charismatic movement is considered a global movement by analysts, so we find formulas like "global Pentecostalism" or "global Charismatism" ". The movement received several classifications based on the specific historical or theological emphasis given by the groups of the movement. Thus, we find variants which divide them into Classical Pentecostals, indigenous churches and Charismatics ${ }^{4}$ or into Classical Pentecostals, Protestant Charismatics, Charismatic Catholics, the independent groups and the indigenous groups in the Third World. ${ }^{5}$ The simplest and the most relevant form is the division into Classical, Charismatic and Neo-Charismatic Pentecostals ${ }^{6}$ adopted for this study.

Methodologically, the study will analyze the first three waves of the Pentecostal-Charismatic movement, then it will search for the distinctive elements of the movement and finally it will evaluate it through some basic observations.

\footnotetext{
2 Synan mentions the Holiness Pentecostal Church in Goldsboro, North Carolina, established in 1898 (http://www.pctii.org/arc/synan.html) the Pentecostal Churches of America in Brooklyn, New York, established in 1894 and the Pentecostal Mission in Nashville established in 1898. See: Vinson Synan, The Holiness-Pentecostal Tradition, Grand RapidsCambrige 1997, p. 48-49. One can also include here the churches in the Pentecostal Church of the Nazarenes established in 1895, which has later abandoned the term "Pentecostal" in its name.

3 Allan Anderson, Michael Bergunder et al. (eds.), Studying Global Pentecostalism. Theories and Methods, Berkeley-Los Angeles-London 2010.

4 Walter J. Hollenweger, Pentecostalism. Origins and Developments Worldwide, Grand Rapids 2005, p. 2.

5 V. Synan, "Pentecostalism:Varieties and Contributions", in: Pneuma: The Journal for the Society of Pentecostal Studies 8 (2/1986), p. 32-34.

6 Stanley M. Burgess, Eduard M. van der Maas (ed.), The New International Dictionary of Pentecostal and Charismatic Movements, Grand Rapids 2002, p. 20.
} 


\section{The First Wave: The Classical Pentecostals}

The concept of "Pentecostal" was adopted with great debate. The Pentecostal movement claims its roots in the so-called holiness movement of the Nineteenth Century. One of these movements, known as Holiness ("holiness" as doctrine of sanctification), was born in the Methodist tradition ${ }^{7}$ its name showing the theological and practical line of the churches it reunited. Methodism gave the signal of searching for the personal sanctification as a new stage in the Christian's life. After conversion, Methodists said, one needed to achieve growth in holiness ending up with the "entire sanctification".

\section{Historical Aspects}

The period of the great spiritual revivals of the eighteenth and nineteenth centuries was coming to an end. Many Evangelical Christians were living with the nostalgia of the conversions and the supernatural phenomena that have accompanied these revivals. The spirit of revival and spiritual renewal had to be continued. Thus, for almost thirty years (1867 - 1894) the Methodist leaders in the eastern United States organized the "crusade of sanctification" with outdoor meetings, attended by several Evangelical denominations (Methodists, Baptists, Presbyterians, Congregationalists) which, without knowing it, were preparing the birth of Classical Pentecostalism ${ }^{8}$. The Holiness Movement was using the term Pentecostal with reference to the work of the Holy Spirit during the birth of the Church described in Chapter 2 of the book of Acts, but the term did not have the resonance of the term used after the formation of the first Pentecostal churches. This resonance was later directly related to the gift of speaking in tongues.

The Pentecostal Movement began by having as its main motivation the manifestations of the supernatural or miraculous gifts (speaking in tongues and their interpretation, prophecy and healing). The idea of baptism with the Holy Spirit as "baptism of fire" was present in the sermons and the thinking of Benjamin H. Irwin, one of the leaders of Holiness?

\footnotetext{
7 John Wesley (1703-1791) has been called "the strenuous founder of Methodism and was also the spiritual and intellectual father of the modern movements and of Pentecostalism." See: V. Synan, The Holiness-Penticostal Tradition., p. 1.

8 See: Vinson Synan, The Holiness-Pentecostal Tradition, p. 27; Melvin E. Dieter, The Holiness Revival of the Nineteenth Century, Lanham-Folkestone 1996, p. 79.

9 V. Synan, "Irwin, Benjamin Hardin" in: James F. Puglisi, Stefan Tobler, Testimoni della fede nelle Chiese della Riforma, Rome, 2010, p. 202-204. Also see V. Synan, The Holiness-Pentecostal Tradition, p. 51-60. Benjamin Hardin Irwin was the founder of The Fire-Baptized Holiness Church which emphasized a third experience, ulterior to conversion and sanctification, namely the experience of baptism with the Holy Spirit and with fire. Irwin was especially
} 
Nevertheless, sanctification claimed more than a model Christian moral: it claimed a new baptism (a new immersion) in the power of the Spirit! The centre of gravity moved from the doctrine of sanctification to a doctrine about the baptism with the Holy Spirit. This did not mean to neglect the doctrine of sanctification, but the order was determined by the need for spiritual renewal with support from the miraculous gifts. Therefore, in the mid-nineteenth century, the new concept "baptised in the Spirit" replaced the classical Methodist concepts like "death to sin", "circumcision of the heart" or "total consecration crisis".

The events that have lead to the birth of the Classical Pentecostalism succeeded very quickly and the written reports do not help us understand what happened then. The first leaders of the movement were Charles Fox Parham (1873-1929) and William Joseph Seymour (1870-1922) ${ }^{10}$. Charles Parham was the headmaster of a Bible school in the town of Topeka, Kansas. Parham was already fascinated by the idea of sanctification through searching for a separate baptism of the Holy Spirit in accordance to Benjamin Irwin's thinking. ${ }^{11}$ On the first day of the New Year, in 1901, while praying, Parham laid his hands, among others, on a student named Agnes Ozman, who started speaking in tongues. In fact, this gift was the gift of speaking in Chinese. After this, Ozman could not speak English for three days. ${ }^{12} \mathrm{~A}$ few days after this date, together with other members of the school, Parham received the gift of speaking in tongues. Five years later, in 1906, on Azusa Street in Los Angeles, California, in a building where meetings, led by Pastor William Seymour, were held there were experiences similar to the ones in Topeka. The building was opened to all those willing to be filled with the power of the Holy Spirit. Thousands of believers from various churches visited the congregation meetings several times a week. Azusa Street in Los Angeles became a sort of "American Jerusalem" for the Pentecostals around the world.

"Pentecost has come to Los Angeles, the American Jerusalem. Every sect, creed, and doctrine under Heaven is found in Los Angeles, as well

influential among southern Methodists in the United States, but the claim that he himself has reached the stage of perfection and his teaching about several baptisms have led to the stigmatization of the movement and to his own stigmatization.

10 Glenn W. Gohr, "Seymour, William Joseph” in: James F. Puglisi, Stefan Tobler (eds.) Testimoni della fede nelle Chiese della Riforma, Roma 2010, p. 339-343; Gaston Espinoza, William J. Seymour and the Origins of Global Pentecostalism. A Biography and Documentary History, Durham, NC 2014.

11 V. Synan, The Holiness-Pentecostal Tradition, p. 59.

12 Roberts Liardon, The Azusa Street Revival, Shippensburg 2006, p. 73-74. 
as every nation, [...] sent of God for 'Pentecost' ... Surely we are in the days of the restoration, the 'last days,' wonderful days, glorious days". ${ }^{13}$

Note that Seymour attended Parham's Bible courses in Houston, Texas, which made him determined to preach the same explanatory principle of the new movement: "He who does not speak in tongues is not baptised in the Holy Spirit". Thus the two, Parham and Seymour, can be considered the founders of the Pentecostal movement based on the doctrine that the baptism in the Holy Spirit's first visible evidence is the gift of speaking in tongues.

William Seymour was raised as a Baptist, his parents were former slaves. He became a preacher of the Holiness movement, although he was not a native speaker and did not have any theological studies. The ideas of the movement strongly influenced by the Arminian and Dispensational ideas, did not match the Baptist ones. Thus, a group of Baptists were expelled from their churches for teaching the doctrines of the Holiness movement. They asked William Seymour to be their pastor and he spent some time under the influence of the spiritual awakening of those times. Seymour reconsidered his pneumatology after a few experiences of prayer for some people close to him (Edward Lee, Jennie Moore and others) who spoke in tongues. Finally, after several weeks of prayer, Seymour himself received the gift of tongues. At first the meetings were held in homes and then they moved to the streets, eventually reaching Azusa. The first official meeting of the church led by Seymour was held on April 14, 1906. A few days later, on April 19, there was a great earthquake in the area which killed thousands of people. The event led to an explosion of participants in the small Pentecostal church on Azusa Street. It is said that by September, church meetings were attended by over 13,000 people. The assembly consisted mostly of African Americans; the meetings then grew in number and were described as extraordinary but chaotic events. Seymour rarely preached and he usually asked the people present to let the gift of tongues descend upon them. The gift descended upon some, but the strange events dominated the meetings: animalic screams, dancing to exhaustion, running, screaming, fainting, crying etc. Subsequently, one noted occult invasions which were difficult to separate from the authentic experiences. ${ }^{14}$ Charles Parham visited California and spent some time with Seymour and his church but what he saw there terrified him. He writes:

"I hurried to Los Angeles, and to my utter surprise and astonishment I found conditions even worse than I had anticipated. Brother Seymour

13 Frank Bartleman, How Pentecost Came to Los Angeles. As It Was in the Beginning, 2 $2^{\text {nd }}$ edition, Los Angeles, 1925/1962 p. 63-64.

14 See F. Bartleman, How Pentecost Came, p. 61, 69. 
came to me helpless; he said he could not stem the tide that had arisen. I sat on the platform in Azusa Street Mission, and saw the manifestations of the flesh, spiritualistic controls, saw people practicing hypnotism at the altar over candidates seeking the baptism; though many were receiving the real baptism of the Holy Ghost." ${ }^{15}$

Seymour decided to set up the Apostolic Faith Movement, being helped by several women. For three and a half years the work of the new movement continued unabated. But the missionaries who had hoped to receive the gift of speaking in known tongues (as in the case of Agnes Ozman) failed. However, the spirit of spiritual revival was carried on in the world by those who came to the Azusa Street meetings. There were often scandals and divisions between the leaders of the churches who were either for or against the Movement.

The spirit of challenge and the Pentecostal ideas and practices were accompanied by the spirit of division. Many Classical Evangelical churches suffered because of this. Some leaders have moved to the new movement with the whole congregation, others were excluded by their assembly. The churches of the Holiness movement were devastated by the rise of the Pentecostal movement. ${ }^{16}$ As time went by, the movement gave birth to hundreds (some say thousands) of new assemblies and denominations. After the separation from Parham, Seymour distanced his doctrine from William Durham's ${ }^{17}$ doctrine in Chicago. The reason was that the two did not preach the same doctrine of the baptism in the Holy Spirit. Durham did not accept a second blessing as sanctification, because, he said, the divine grace decisively worked only once. His position maintained the conversion as the "finished work" of the grace at Calvary and sanctification as a process.

Durham explains his theological position as opposed to that of John Wesley:

"To my mind the second work theory is one of the weakest and most unscriptural doctrines that is being taught in the Pentecostal movement

15 Sarah E. Parham, The Life of Charles F. Parham, Founder of the Apostolic Faith Movement, Baxter Springs 1930, p. 165-167.

16 A representative of the Holiness movement, Alma White, called Pentecostalism "the greatest religious farce that has ever camouflaged under the name of Christianity." Susan C. Stanley, "Alma White: The Politics of Dissent," in: Portraits, p. 62; cited in R.G. Robins, Pentecostalism in America, Santa Barbara 2010, p. 33.

17 William Howard Durham (1873-1912), a former Baptist who has initially followed a Reformed theology, was living in Chicago, but in 1907 he visited the Azusa Street Mission in Los Angeles; upon his return he decided to join the Pentecostal movement. Although he has lived a short life, he was highly influential especially because of his soteriology, his work of mentoring and the Pentecostal Testimony publication. See: R. G. Robins, Pentecostalism in America, p. 38-42. 
and therefore ought to be ruled out as damaging. If sanctification were a second definite work of grace, the Scripture would certainly contain instances where some one received such an experience. But while one instance after another of conversion and receiving the Holy Spirit is recorded, not one single case is recorded where any one got sanctified as a second, instantaneous work of grace. The reason is no such thing ever happened. There is none to record. Nor do the advocates of the second work theory today attempt to prove it from the Scriptures. Some of them attempt to prove it by misapplication or misrepresentation of Scripture. Most of them however simply refer us to the teaching of Mr. Wesley, or some other good man, and seem to expect that we will accept them as authority, whether their teaching is Scriptural or not. Many seem to expect that we will accept their personal testimony instead of the plain teaching of the Word of God. Now we believe Mr. Wesley and many others who have taught the second blessing doctrine were real men of God, but we believe that they were mistaken in this matter. We believe God raised up Mr. Wesley to preach holiness unto the Lord, and that his message was a great blessing to the world, but we do not believe that God sent him to preach that holiness or sanctification was and could be received only as a separate and distinct work of grace. Again I can nowhere find where Wesley ever taught dogmatically that sanctification is and must be a second instantaneous work". ${ }^{18}$

Those who were preaching like Durham, i.e. a baptism of the Spirit only in two stages, formed a new denomination in 1914 known as the Assemblies of God, the largest Pentecostal group today. Two years after this separation, the Pentecostal movement had three main branches that have remained unchanged to this day. The first was following the Wesleyan line of the "entire sanctification", the second was following the line of the "finished work" and the third one the non-Trinitarian line. Dozens or hundreds of denominations lined up along these lines over the years.

\section{Theological Issues}

From the beginning the Pentecostal movement has put less emphasis on education and more on experience. The Bible was rarely read during the Pentecostal meetings. But prophecies abounded, especially those about the end of the world. The teaching that speaking in known tongues will help missionaries to evangelize the world has disappointed many because it was not the case in practice. On the other hand, the teaching about speaking in

18 Douglas Jacobsen (ed.), A Reader in Pentecostal Theology. Voices from the First Generation, Bloomington 2006, p. 82-83. 
unknown tongues was more popular. In public meetings, pastors requested the testimony of those who have had the experience of speaking in tongues. However, these testimonies rarely included references to forgiveness and the relationship with Jesus Christ. The distinctive sign of baptism, the tangible proof of the presence of the divine reality was the important element. It was no longer enough to give signs of personal sanctification such as in Methodism and Holiness. Pentecostalism showed signs of expressing the supreme ecstatic state of the Christian experience.

After the special events of the early Pentecostalism, one tried a clearer localization of the movement both theologically and historically. Who were actually the first Pentecostals? Before the supposed experience of speaking in tongues, these Christians were Methodists, Baptists, Nazarenes, etc. How did it happen that they so quickly and so convincingly embraced the new denomination? The reasons were sought in several places but source was certain: the essence consisted in encouraging different scale repetitions of the experience of baptism with the Holy Spirit at Pentecost as a necessity for a full spiritual life. This experience was ulterior to, not simultaneous with conversion. William Menzies, historian of the Pentecostal branch Assemblies of God, defined the Pentecostal movement as:

"that group of sects within the Christian Church which is characterized by the belief that the occurrence mentioned in Acts 2 on the day of Pentecost not only signaled the birth of the Church, but described an experience available to believers in all ages. The experience of an enduement with power, called the "baptism in the Holy Spirit" is believed to be evidenced by the accompanying sign of "speaking with other tongues, as the Spirit gives utterance." ${ }^{19}$

Pentecostals therefore had as a reference point the model of the early Church when the early Christians experienced the enduement with power for life and service, having in the gift of speaking in tongues the visible evidence of the baptism in/with the Holy Spirit. In the ecclesial practice, the Lucan text in Acts 2 must be corroborated with the Pauline text of 1 Corinthians 12-14 in order to understand the importance that the spiritual gifts have in the public worship.

Although initiated by a single desire- that of experimentation of baptism with the Holy Spirit, the Pentecostal movement was divided very quickly. ${ }^{20}$

19 William W. Menzies, Anointed to Serve. The Story of the Assemblies of God, Springfield 1971, p. 9.

20 For example, in Pentecostalism there are two main branches: the Trinitarian one and the Unitarian one. Unitarian (Oneness) Churches such as the "United Pentecostal Church International" and "Pentecostal Assemblies of the World" are not present in the classical 
Most of the reasons of this division are conceptual reasons. In principle, the Pentecostal doctrine kept the major doctrines of the Evangelical movement. Specific for the Pentecostal theology was soteriology, while maintaining justification as a declaratory act and sanctification as a process, pneumatology with the overemphasis of baptism with the Holy Spirit and eschatology with the return of Christ and the rapture of the saints. Like any religious movement, Pentecostalism is based on a kind of hermeneutics that faithfully reflects the traditional heritage. Since there are so many interpretations of the work of the Spirit in the believer and in the Church one cannot speak of a single hermeneutics method embraced by all Pentecostals. The diversity of the theological interpretations betrays the guiding principle: before having the interpretation one has the experience.

"The very act of becoming a Pentecostal was in a certain sense a function of the theological labels one used to describe one's religious experiences. Experience alone did not make one a Pentecostal. It was experience interpreted in a Pentecostal way that made one a Pentecostal" 21 .

For a Pentecostal, order matters: the experience of baptism in the Holy Spirit comes first and then one seeks its interpretation. The distinctive elements of the Pentecostal hermeneutics vary. Roger Stronstad has synthesized them in the pragmatic, pneumatic, literary and holistic dimension. ${ }^{22}$ The first one, the pragmatic dimension, was developed by Charles Parham, though he was not a specialist in the biblical theology. For example, Parham understood the tandem "spring rain" and "autumn rain" (Joel 2:23) as referring to the birth of the Church at Pentecost, thus to the birth of the Pentecostal Church. The "autumn rain" announces the end of time and the Church of Christ is called to preach it. In Parham's biography- written by his wife- one can find the concept about baptism with the Holy Spirit and the restoration of the spiritual gifts. ${ }^{23}$ In one of his explanations, Parham wrote:

"The anointing of the Holy Spirit is given to illuminate His Word, to open the Scriptures, and to place the spiritual man in direct communication with the mind of God; man will be in instant communication

Pentecostal organizations like "World Pentecostal Fellowship", "The Pentecostal Fellowship of North American" or "The National Association of Evangelicals" . See Bennie S. Triplett, $A$ Contemporary Study of the Holy Spirit, Cleveland 1970, p. 22.

21 D. Jacobsen, Thinking in the Spirit. Theologies of the Early Pentecostal Movement, Bloomington 2003, p. 3.

22 See: Roger Stronstad, Spirit, Scripture and Theology: A Pentecostal Perspective, Baguio City, Philippines 1995.

23 S. Parham, The Life of Charles F. Parham, p. 52-53. 
with the mind and will of God, and not only so, but to directly connect this mind with your spirit. This is occultic in the sense that the mind of the spirit in you becomes the receptacle for the thought waves of wisdom that have been let loose by the minds of the church of the past ages, until the wisdom of the ages, floating ever upon the waves of ether, are at your command to draw from. This is a profound, though little understood, truth". ${ }^{24}$

A few decades later, the Pentecostal biblical scholar Gordon Fee summarized best Parham's hermeneutics noting that it "fulfills what can be understood literally, spiritualizes, allegorizes and devotionalizes the rest." 25

Moving on towards the contemporary period, the historical theological studies $^{26}$ show how the Pentecostal theologians saw the need of another type of hermeneutics, especially applied to the biblical narratives of the Book of Acts and the Pauline Epistles. Here things were simplified as the Pentecostals exegetes have decided to use and extend Paul's method to extract the doctrinal principles of the biblical narratives. This has led to emphasis on the pneumatological continuity and homogeneity of the Lucane writings. The doctrine of the Holy Spirit was present not only in the Luke-Acts tandem, but also in Paul's Epistles, along the particular doctrine of baptism in the Holy Spirit. The contrast between the two types of theology was obvious: the Lucan theology considered the dynamics of Christian service, while the Pauline one considered the dynamics of salvation. In other words, the former aimed more at sanctification, the latter aimed at justification. Although they appear as two different theologies, they must complete each other. The Pentecostal theologians have decided which had to be a priority in hermeneutics when they had to apply it in the Pentecostal practice. It was not hard to decide and they preferred the Pauline theology to the Lucan one ${ }^{27}$.

The problem arises when trying to standardize the experiences with the Holy Spirit. Can the narrative biblical texts become normative? Gordon Fee is

24 D. Jacobsen (ed.), A Reader in, p. 42.

25 Gordon D. Fee, "Hermeneutics and Historical Precedent. A Major Problem in Pentecostal Hermeneutics", in: Russell P. Spittler (ed.), Perspectives on the New Pentecostalism, Grand Rapids 1976, p. 121. Cited in: Constantin Macoveiciuc, Continuity and Doctrinal Diversiy in the Classical Penticostalism and in the Charismatism Today, Bucharest 2009, note 52.

26 See a list of article mentioned in: F.L. Arlington, "Hermeneutics, Historical Perspectives on Pentecostal and Charismatic", in: S.M. Burgess, G.B. McGee, (eds.), Dictionary of Pentecostal and Charismatic Movements, 1995, p. 376-389.

27 The strongest arguments of the Pentecostal hermeneutics of Lucan origin come from Roger Stronstad, The Charismatic Theology of St. Luke, Peabody MS 1984; Idem, Spirit, Scripture, and Theology: A Pentecostal Perspective, Baguio City, Philippines 1995; Idem, The Prophethood of all Believers. A Study in Luke's Charismatic Theology, London-New York 1999/2003. 
very cautious when seeking hermeneutical support for the classical Pentecostal texts. Fee notes that the two Pentecostal sources- the Biblical analogy and the Biblical precedent - do not always work pertinently. For example, the analogies referring to the spiritual experiences before the events in Acts 2 cannot be considered normative; maybe some of them, but not all. As for the biblical precedent, Fee is reluctant to normatively relate the baptism in the Holy Spirit to the visible proof of it, i.e. speaking in tongues. The writer of the Acts had no such primary intention. ${ }^{28}$ This applies only when relating to the biblical narration. Nevertheless, hermeneutics changes when one moves to the level of the personal experiences. A historical precedent may suggest that the experiences involved in the event can be repeatable, obviously referring to the experience of baptism in the Holy Spirit. But for Fee, paradigms are not normative. ${ }^{29}$

Another option would be that the repeatability of certain descriptive elements can make the tranzition to the prescriptive elements. Most of the Pentecostal exegetes choose this alternative. ${ }^{30}$ The support comes with the Pentecostal theology regarded as an encounter between God, the Scripture and the community. The Holy Spirit is God who communicates the revealed truth and inspires the Biblical authors. Nevertheless, the correct interpretation of the revealed text is accomplished through by the mediation of the Spirit. Here one can find the pneumatological principle of interpretation of the Scripture; the spirit is stronger than the letter. He who has inspired the text makes the best interpretation of it. This process is called not a new revelation, but a simple enlightment. ${ }^{31}$ However, the interpreters themselves must be regenerated by the Holy Spirit. As there was the Incarnation of the Logos which has brought us the truth, there is a divine-human incarnation in the interpretation of the written Word. After man does his part (the careful analysis of the text) the Spirit is called upon through prayer to illuminate the mind in an act of invisible but real meeting between man and divinity. ${ }^{32}$ In this way, the Pentecostal hermeneutics integrates experience in theological knowledge. The Holy Spirit thus makes contact with the Christians in the first century

28 Gordon D. Fee, Gospel and Spirit: Issues in New Testament Hermeneutics, Grand Rapids 1991, p. 94-98.

29 Gordon D. Fee, "Baptism in the Holy Spirit: The Issue of Separability and Subsequence" in: Pneuma 7 (2/1985), p. 87-99.

30 For example David Petts, "The Baptism in the Holy Spirit: The Theological Distinctive" in: Keith Warrington, Pentecostal Perspectives, Milton Keynes 1988, p. 98-119; John F. Tipei, The Holy Spirit: A Biblical Theology from the Pentecostal Perspective, Oradea, 2003, p. 254.

31 Stanley M. Horton, "The Pentecostal Perspective", in: Five Views of Sanctification, Oradea 1999, p. 127.

32 Howard M. Ervin, "Hermeneutics: A Pentecostal Option" in: Pneuma, 3 (2/1981), p. 31. 
Church through an experiential act. If the transition is possible, why would the first century Christians' experience at Pentecost not be possible for the twenty-first century Christians? Consequently, why would the Christians today not benefit from all the manifestations and gifts of the Spirit in the first century? Pentecostals have given an answer to the rhetorical questions and have tried to apply the theory in practice. Such a hermeneutics will not jeopardize the interpretation of the sacred text, if each experience is verified in the light of the text. ${ }^{33}$

Specifically, the Pentecostal theology has reinterpreted the doctrine of baptism in the Holy Spirit. The doctrine was also present in other Protestant traditions, but the Pentecostal movement gave it a more special role. In the Methodist theology, outlined by John Wesley and John Fletcher, the ground has already been prepared for the development of the doctrine of baptism in the Holy Spirit. The Methodists were leaving room for two stages in the Christian life: one referring to the act of justification by faith and the other one to the instantaneous experience of the entire sanctification. The Methodists' ideas were then adjusted in the nineteenth century by A.J. Gordon, Charles Finney, Andrew Murray, AB Simpson F.B. Meyer ${ }^{34}$, making room for the experience of baptism in the Holy Spirit but relating it to the service in some spiritual work. The American Methodists drew the line and those who rejected the doctrine of the entire sanctification founded the Holiness movement. The British version of Holiness was also born during the nineteenth century Holiness movements and it was named the Keswick Movement (Keswick is the town in northern England where the meetings were held); the movement considered that the experience of baptism in the Holy Spirit came after conversion and was essential for a life of victory through faith and for the power of testimony. In the United States two great preachers, D. L. Moody and R. A. Torrey supported the idea of two works of grace without automatically associating them with the gift of speaking in tongues. When the early Pentecostal leaders defined the baptism in the Holy Spirit, in addition to the conversion and the sanctification of heart they also added a third

33 For more details, see William Menzies' proposal in “The Methodology of Pentecostal Theology: An Essay in Hermeneutics" in: P. Elbert (ed.), Essays on Apostolic Themes: Studies in Honour of Howard M. Ervin, Eugene OR 1985, p. 1-14. Scott A. Elllington's article "Locating Pentecostals at the Hermeneutical Round Table" in: Journal of Pentecostal Theology, 22 (2013), p. 206-225 is interesting and revealing for the Pentecostal hermeneutics today.

34 These are considered the leading theologians, preachers and writers of the nineteenth century who have established the doctrine of baptism with the Holy Spirit of the future Pentecostal movements. For references on their influence, see Frederick D. Bruner, $A$ Theology of the Holy Spirit. The Pentecostal Experience and the New Testament Witness, Grand Rapids, 1970, p. 44-45, especially note 28. 
work of grace: baptism in the Holy Spirit. This addition was not appreciated by most Pentecostal theologians leading to the major separation of the Churches. That is why most Pentecostal denominations have supported the paradigm of the two stages of the work of grace (conversion and baptism in the Holy Spirit).

What all the Pentecostals have in common can be found precisely in this second stage in which the experience of the presence of the Spirit in the believer's life is noticeable. A proof is the empowerment for a particular service by endowing the believer with spiritual gifts. From the beginning it was stipulated that the new work of the Spirit had nothing to do with the salvation of the believer. Baptism does not condition salvation. The gift of the Spirit is given after conversion. The spiritual power received by Christ's disciples at Pentecost did not imply their conversion, but the empowerment for the new work in and through the Church (Acts 1: 8). It was also the case of the Samaritans in Acts 8 when they were converted first, then they received the Holy Spirit, meaning that they were empowered from God. Then there was Paul's conversion, seconded by the empowerment with the Spirit (Acts 9:17). As for the group in Cornelius' house (Acts 10) they received the Holy Spirit after they had repented. There was some time between conversion and baptism in the Spirit, but it did not matter too much. Conversion and baptism are separated only logically, not chronologically in the text. The last text that directly relates to the baptism in the Holy Spirit is about John's disciples (Acts 19). These disciples had faith, but they did not know the doctrine of the Holy Spirit and therefore lacked the empowerment of the Holy Spirit. After receiving the Holy Spirit they were no longer ignorant. In some cases this empowerment with the Spirit came through laying hands on the person, in other cases it came through the person's request. Consequently, the cases of the early church described in Acts are evidence of a baptism with the Holy Spirit, evidence of conversion, of the time when the re-born Christians start their new lives and/or the moment of empowerment for the spiritual work. This experience is not a secret known only by some intiated people, but is available for every Christian.

\section{The Second Wave: Charismatics}

When the Charismatic movement began after World War II, it was necessary to clarify its name. Thus, some suggested that the new Charismatic movement should be called "Neo-Pentecostalism", but many Pentecostals did not accept the term. At first, a Charismatic was considered to be a person who has experienced the baptism in the Holy Spirit without leaving the de- 
nomination to which they belonged. ${ }^{35}$ It seemed unnatural to relate the new movement to the Classical Pentecostalism. The Charismatic Catholics, for example, have used the phrase "Catholic Pentecostals" instead of "Charismatic Catholics." 36 This shows closeness to Pentecostalism, without there being any important contacts between the two groups.

It is true, however, that the increasing presence of some Pentecostal leaders in the media (radio and television) as well as the influence of some non-profit Pentecostal organizations and the openness to a ready ecumenism have somewhat prepared the birth of the Charismatic movement in the 60s. ${ }^{37}$ In a first stage, the Charismatic movement was limited to the Protestant churches. St. Mark Episcopal Church in Van Nuys, California is recorded in the history of the movement as the first Non-Pentecostal church which recorded the baptism in the Spirit accompanied by speaking in tongues, even by the congregation's priest, Dennis Bennett. He made public his and other believers' experience on April 3, 1960, sparking controversy and amazement. The Lutheran church of San Pedro and its priest, Larry Christenson was next. In 1962, the signs of the new movements were present in an Anglican church in London where Michael Harper served as priest. Germany had the charismatic experience of a priest named Arnold Bittlinger.

After nearly ten years of Charismatic signs only in the Classical Protestant churches, it was the turn of the Catholic churches to talk about them. One effect of The Second Vatican Council was to encourage Catholics to pray with the Christians from other churches. The encouragement was taken seriously. Thus, two professors from Duquesne University, Ralf Kiefer and Bill Storey, along with students and graduates of the school, witnessed the work of the Spirit in their lives by speaking in tongues, prophecies and visions. To these were added several strange events such as the holy laughter or rolling on the floor. The centre of the Catholic Charismatic events then moved to the University of Notre Dame where meetings were held with charismatic topics, with mixed participation, however dominated by Catholics. In the following years, the movement spread among Catholic priests, schools and local=parishes in Europe. In 1975 25,000 Charismatic Catholics accompanied by leaders and church choirs gathered to celebrate The Descent of the Holy Ghost at St. Peter's Cathedral in Rome ${ }^{38}$.

\footnotetext{
35 V. Synan (ed.), Aspects of Pentecostal-Charismatic Origins, Plainfield, NJ 1975, p. 1-2.

36 Kevin Ranaghan, Dorothy Ranaghan, Catholic Pentecostals Today, Mahwah NJ 1969, p. 70.

37 We refer here to leaders such as Oral Roberts, Demos Shakarian or David du Plessis.

38 For information about the beginning of the charismatic movement see Eddie L. Hyatt, 2000 Years of Charismatic Christianity, Lake Mary 2002, p. 175-179; Richard Quebedeaux,
} 
In principle, the charismatic meetings resembled the Pentecostal ones in what worship was concerned. The common prayers, the persuasive sermons, the personal testimonies and the manifestations of some miraculous gifts dominated the service. Home fellowship groups and centers of healing or prophecy were also encouraged. Also, the secular nature and the focus on the work of each member of the congregation were specific to these meetings. But there were also extreme forms of charismatic manifestations condemned by everybody.

On the one hand the Charismatic Movement has caused concern among the traditional churches, but on the other hand it has forced them to rethink the dynamics of the spiritual life. The Charismatism present in the Evangelical churches sanctioned the spiritual rigidity of the traditional churches and the Evangelical rationalism. It was a warning and an option. Of course, the Charismatic phenomenon was analyzed carefully in many churches and the majority of the conclusions drawn were favorable to the movement. Many churches have decided not to oppose the new Charismatic wave, but to leave it open. Even the Roman Catholic Church appointed special committees to assess Charismatism and concluded that the positive elements brought by the movement outnumber the negative ones ${ }^{39}$. The movement was labeled as a sign of hope and therefore had to be correctly integrated into the life of the local churches.

Not all churches have seen this movement as favorable. The main criticism was about the overuse of the subiective experiences in prejudice of the authority of the objectively revealed Word. Charismatism also created the context for the formation of the spiritual elitism and miracle-mania.

\section{The Third Wave: Neo-Charismatics}

It was not long after the start of the Neo-Pentecostal wave that, after 1985, the Charismatic movement entered a new phase, known as the "Third Wave" or the "Neo-Charismatism" phase. The term was launched by Peter Wagner, professor of theology at Fuller Seminary in Los Angeles, California ${ }^{40}$. The first wave was referring to the Classical Pentecostalism, the second

The New Charismatics. The Origins, Development and Significance of Neo-Pentecostalism, New York 1976; V. Synan, The Holiness-Pentecostal Tradition, p. 234-252.

39 Synan, for example, cites a report of the Catholic Bishops Commission for doctrine in 1969 which encourages the movement. See: Kilian McDonnell (ed.), Presence, Power, and Praise, vol. 1, Mahwah NJ 1980, p. 207-210, cited by V. Synan in: The Holiness-Pentecostal Tradition, p. 251.

40 See: C. Peter Wagner (ed.), The New Apostolic Churches, Ventura, 1998. 
wave to the Charismatism in the Non-Pentecostal churches and the third wave to the Neo-Charismatism in the Conservative Evangelical churches. The division is subjective of course, many Evangelical theologians refusing such an association.

Peter Wagner and his colleague, John Wimber, have set up a new denomination with the participation of the Vineyard churches ${ }^{41}$; here baptism in the Holy Spirit manifested not only through the Charismatic classical forms (speaking in tongues and prophecies), but also through new forms, given by the "liberation of the Spirit". The new manifestations included tremor, spiritual ecstasies, "killing in the Spirit", animalic sounds etc. ${ }^{42}$ Wagner and Wimber have originally named this as "Signs and Wonders Movement". A typical example of the new Charismatism is that of the Evangelist Rodney Howard Brown, who, in March 1993, arrived in the state of Florida for a week of Evangelism but after several days of work marked by thousands of conversions and strange events, extended his stay for 14 weeks. After such a meeting, Randy Clark of Toronto, Canada, returned to his church wanting to extend these free events. Thus, in 1994, a new phenomenon called "Toronto blessing" started at the Toronto Airport Vineyard Church, under the leadership of John Arnott; here the holy laughter, rolling on the floor, the animalic sounds, the prophecies and the scheduled healings became specific for the church near the Toronto airport. ${ }^{43}$ Being considered a spiritual awakening phenomenon, the "Toronto blessing" was repeated in other countries, with hundreds of thousands of conversions. A year later, in 1995, another revival movement headed by John Kilpatrick was recorded in Brownsville, Pensacola, Florida.

The period is also known as power Evangelism and the Charismatic language repertoire enriched with new concepts such as "Rest in the Spirit", "slain in the Spirit" "release service" or "spiritual warfare". In addition to the classic distinctive signs of baptism in the Holy Spirit, one can find an overbidding of the gift of healing which has become almost mandatory for any charismatic meeting. The list of Charismatic leaders has been filled in with new names such as Kathryn Kuhlman, Francis MacNutt, Kim Kollins, Yonggi Cho, Derek Prince, Benny Hinn or Reinhard Bonnke. The list of the mega-churches has also become increasingly long.

${ }^{41}$ Peter Hocken, The Challenges of the Pentecostal, Charismatic and Messianic Jewish Movements. The Tensions of the Spirit, Ashgate, 2009, p. 75-96.

42 E. L. Hyatt, 2000 Years of Charismatic Christianity, p. 197.

43 Margaret M. Poloma, Main Street Mystics. The Toronto Blessing and Reviving Penticostalism, Walnut Creek 2003, p. 59. 
After a while, the initiators of the third wave, Wagner and Wimber, backed out when they saw where the movement was heading. Their questions were related to the incongruity between the biblical signs of a spiritual revival and the exotic uncontrollable signs of the new kind of Charismatic movement. But it was too late. The movement had spread too fast and too uncontrollably. This was the signal of a new beginning for the southern hemisphere. Millions of Christians were yearning for spiritual power which was often seconded by the desire for material prosperity or physical healing. The new type of Charismatism seemed to go too far. To justify its direction, Neo-Charismatism was forcing the biblical text or was separating preferential texts to transform them into standard promises. Experience was beating exegesis! Many meetings had a sacramental tendency by calling upon the mysterious presence of divinity or by diminishing the role of reason and of the Christian tradition.

\section{Distinctive Features}

The three Pentecostal-Charismatic waves have shown an unexpected evolution of the perception of the Christian spirituality. The waves have gradually changed the centre of gravity of the Christian life. From mortification of $\sin$ in one's personal life one came to the need for baptism in the power of the Spirit and then to the use of the power of the Spirit for prosperity. Moreover, the waves have changed the order in the Christian theology. From a theology focused on the work of Jesus Christ as justification by faith, one came to a theology of sanctification towards perfection and then to a theology of spiritual and material welfare. The excessive emphasis on experience has outclassed doctrine. Few of the people who have participanted in the Pentecostal-Charismatic movements wanted to deepen the knowledge of the Christian doctrine. No wonder that the music of the Charismatic movement has come to offer the theology of the movement.

The first major distinction between Pentecostals and Neo-Pentecostals or Charismatics derives from the type of spiritual experience ulterior to conversion and expected from all believers. Pentecostals were limited to the experience of baptism in the Holy Spirit accompanied by speaking in tongues, while Neo-Pentecostals have broadened the paranormal experiences, using prophecies, healings, miracles or physical manifestations with states of altered consciousness. Many Pentecostals do not see this difference and think that the two movements share the same spirituality. Practice however is different. Some Pentecostal leaders distanced themselfs from the Charismatic movement since its very beginning. Likewise, some Charismatic Pentecostals have ignored the Pentecostals' claim that only the gift of tongues should be considered evidence 
of the baptism in the Holy Spirit. Although this spiritual gift can be present, Charismatics say, it is neither mandatory nor the only one available.

When the leaders of the Holiness movement repudiated the first Pentecostals, an essential reason was related to the initial evidence of baptism in the Holy Spirit. Pentecostals insisted on the three obvious cases of Acts (Acts 2, 10,19) when speaking in tongues visibly and audibly expressed the empowerment with the Spirit. In the other two cases (Acts 8.9) either the author of the book did not consider it necessary to repeat the same events or has intentionally let the readers themselves deduct the model of baptism in the Holy Spirit.

However, not all Pentecostals have adopted the exclusivistic position according to which speaking in tongues is the only evidence of receiving baptism. As time went by, several branches of the Pentecostal movement rejected the initial version and came up with other proposals. The reason for this was not to confuse the gift of the Holy Spirit with a simple spiritual gift. ${ }^{44}$ Some Pentecostals even prefer to refer to the gift of speaking in tongues as to known languages, as understood by the Pentecostal pioneers. ${ }^{45}$ Therefore one can find among critics various interpretations of the gift of speaking in tongues. Some have identified the experience with sounds without meaning as in pagan religions, some with a string of words that cannot form a particular language because it lacks vocabulary, morphology and syntax. The toughest critics associate the practice of speaking in tongues with the nearest state of trance, such as dreams and visions or a form of psychological catharsis, a symptom of a readjustment of personality. The tolerant critics mistake speaking in tongues for some incoherent series of ecstatic emissions, in the form of bits of prayers and praise for a miracle of hearing, not of speaking.

William Durham, one of the early Pentecostal leaders, remembers his own baptism in the Holy Spirit, mentioning about speaking in tongues:

"I was overcome by the mighty fulness of power and went down under it. For three hours He wrought wonderfully in me. My body was worked in sections, a section at a time. And even the skin on my face was jerked and shaken, and finally I felt my lower jaw begin to quiver in a strange way. This continued for some little time, when finally my throat began to enlarge and I felt my vocal organs being, as it were,

\footnotetext{
44 William W. Menzies, Robert P. Menzies, Spirit and Power: Foundations of Pentecostal Experience, Grand Rapids 2000, p. 129.

45 William J. Seymour, "The Same Old Way", in: The Apostolic Faith, 1 (9/1906), p. 3. Also see W. J. Seymour, "The Doctrines and Discipline of the Azusa Street Apostolic Faith Mission of Los Angeles, California” in: Larry Martin (ed.), The Complete Azusa Street Library, vol. 8, Joplin, MO 2000.
} 
drawn into a different shape. O how strange and wonderful it was! And how blessed it was to be thus in the hands of God. And last of all I felt my tongue begin to move and my lips to produce strange sounds which did not originate in my mind." 46

The Pentecostal theologians believe- not only based on personal experiences, but also on biblical texts- that in the experience of speaking in tongues one has a speech given by inspiration of the Holy Spirit, which keeps the believer's consciousness and the languages can be either human or angelic. Thus, the languages can be known or unknown to the human beings. The purpose of the known languages is the testimony of the Gospel and the purpose of the unknown languages is to build a personal intimate relationship with divinity. Therefore, these theologians insist, speaking in tongues as the initial evidence of baptism with the Holy Spirit is not synonymous with the gift of speaking in tongues.

From the moment they are baptised in the Holy Spirit, all believers begin to speak in other tongues and might continue to speak in their personal prayer for their own edification. However, not all of these are agents through which the Holy Spirit manifests Himself by speaking in tongues and by the tongues' interpretation in the assembly. ${ }^{47}$

In response, most of the Charismatics see the place and the role of tongues in a different way. Although they support the idea of the two stages of the work of grace, they do not always see the experience of empowerment with the Spirit as the experience of baptism with the Holy Spirit. John Wimber preferred the concept of empowerment to baptism; he also preferred to associate the baptism in the Holy Spirit with the birth in the Holy Spirit or regeneration (of adults). Also, Catholic Charismatics prefer expressions like "newness of the Spirit" or "indwelling" to the baptism with the Holy Spirit. When they mention this second experience, they associate it with the consequences of baptism as a regenerator act (for children) and to the subsequent confirmation in the Catholic faith. There may therefore be a moment in which the believer is aware of the personal powerful presence of the Holy Spirit in their life. The Catholic Cardinal Suenens, who was among the first supporters of the charismatic movement, refers to the baptism with the Holy Spirit as "the gift of bringing up-to-date the grace which has already been received, a release of the Spirit, a manifestation of baptism, a return to life of the gift of the Holy Spirit received upon confirmation, a deep respon-

\footnotetext{
46 D. Jacobsen, Thinking in the Spirit, p. 1.

47 William W. Menzies, Stanley M. Horton: Biblical Doctrines. A Pentecostal Perspective, Springfield 1993, p. 151-152.
} 
siveness and docility to the Spirit." ${ }^{48}$ The inseparable connection between the baptism of the child and the baptism with the Holy Spirit cuts the difference between the Pentecostal and the Catholic Charismatic interpretation. The Evangelical and Protestant Charismatics agree with the gift of speaking in tongues, but not implicitly or normatively related to the baptism with the Holy Spirit. All the spiritual gifts can be initial evidence of the baptism in the Holy Spirit. Interpretations vary, but one can notice the hesitancy towards the Pentecostal position. Most of the reticent positions towards the Pentecostal pneumatology are related to receiving and using the spiritual gifts. They can be present in the born again believer, even though they have not been baptised with the Spirit. Did not apostle Paul write that the Spirit distributes to each one individually as He wills? Why is such credit given to only one gift in the Apostle's consistent list? Hasn't this struggle for some more spectacular gifts (speaking in tongues and their interpretation, prophecy and healing) caused so much division among believers in Corinth? The Pentecostal answer relates to the experience of Pentecost which somehow validates only nine spiritual gifts (also called "gifts of manifestation") set aside for a particular category of people baptized in the Holy Spirit. These gifts are received as a result of perseverance, prayer and faith and their goal is to prepare the church for ministry and anticipate the return of the Lord. The work in the ecclesial community is different from that in the secular communities and therefore the gifts have a special nature. For Donald Gee, the gifts of the Spirit "provide a spiritual capability far mightier than the finest natural abilities... they provide the supernatural basis for a supernatural order of ministry." 49

\section{Conclusions}

The discussion of this theme has led us to several conclusions.

(1) First, the Pentecostal-Charismatic movements of the twentieth century are an extension of the holiness movements of the nineteenth century. This extension has brought changes to the Wesleyan doctrine, meaning that the achievement of perfection did not depend so much on the trial of the saints but on the spontaneity of the baptism in the Spirit. In other words, the believers were brought to perfection more by the plus given by the presence of gifts, not by the lack of sin. Like all the similar previous periods-with reference to the periods of awakenings or spiritual renewals- the Pentecostal-Charismatic movements have experienced the interference of some counterfeit and

\footnotetext{
48 Cardinal Leon Joseph Suenens, A New Pentecost?, New York 1976, p. 81.

49 Donald Gee, Concerning Spiritual Gifts, Springfield 2007, p. 26; cited by C. Macoveiciuc, Continuity and Diversity.
} 
potentially demonic phenomena. These counterfeit phenomena should not make us cancel all the special works present in the authentic experiences. The testimonies of many of those who were directly involved confirm the honest closeness to God, even though they have resorted to some non-traditional means. Some experiences have resulted from perseverance in prayer, others have appeared spontaneously; some events have been perceived consciously, others less consciously.

(2) Then, we note the fact that the spiritual leaders had a special role in these movements. The intensity or the interpretation of the events was often related to the charisma and intelligence of the leaders. Moreover, some groups of the Pentecostal-Charismatic movements were given the names of their leaders. ${ }^{50}$ In time, these groups renounced their personal name and adopted names which were typical for the movement. However, the spiritual leaders dominated the meetings by their personality or their gifts which were either natural or spiritual. The lack of theological training of many Pentecostal and Charismatic leaders, especially in the beginning was felt in the economy of the movement. It was hard to repair some hasty or wrong teachings. A recent analysis of the theology of Charles Parham is eloquent. Jacobsen describes how, at one point,

"By this point, Parham had moved to the very edge of the holiness movement and even beyond it. He was struggling to bring together a number of fairly radical convictions that he had embraced but did not yet know how to combine into a coherent system of theology. He was deeply immersed in apocalyptic speculation regarding the end of the world. He was convinced that healing was an integral part of Christian ministry. He believed that all Christians should experience a special baptism of the Holy Ghost. He was sure that a new wave of world evangelism was about to commence, and he believed that at least some people were being specially gifted by God with the miraculous ability to speak foreign languages without training to help them in that task". ${ }^{51}$

But with the emergence of the Charismatic movement, the Pentecostal theology felt obliged to define itself more clearly, which meant a big step forward in the academic field. Then new competent theologians, new theological seminars and publications appeared and they were appreciated by the Evangelical academic community.

50 For example, James Alexander, Apostolic Faith, Franklin Hill, Vernon Mission, Elmer Fisher, Upper Room Mission, Joseph Smale, First New Testament Church, Arthur Osterberg, Full Gospel Mission, Durham, Seventh Street Mission. See: R.G. Robins, Pentecostalism in America, p. 33.

51 D. Jacobsen, Thinking in the Spirit, p. 25. 
(3) We also notice that the manifestations of the spiritual experiences in the two basic movements were never limited. In contrast, the variations of the manifestations have emerged as a characteristic of the Pentecostal-Charismatic phenomenon. Thus, some Pentecostal theologians have shifted away from the initial claim that the gift of speaking in tongues should be considered the only sign of the true baptism in the Holy Spirit. This idea had support neither in the history of revivals and spiritual renewals nor in the history of the classical Pentecostal movements of sanctification.

(4) The criteria to verify the authenticity of baptism with the Holy Spirit expressed through gifts reveal the difficulties of the movement. One of the problems of these movements, for example, is related to the incompatibility between the spiritual experiences and the immorality of those involved, especially leaders. How can one claim to have certain spiritual gifts for the community of believers and live consciously while committing some serious sins? This question is difficult to answer. Some try to separate the spiritual gift from character, but it is impossible from the Christian spirituality perspective. A genuine spiritual work keeps them together. Therefore, an absolute decisive criterion to verify the authenticity of the work is the gift- character tandem. The true spiritual manifestations also have to be subordinated to the biblical principles. The claim of some prophets of the Pentecostal-Charismatic movement to have had new revelations that would complement the biblical revelation is unacceptable. A relaxed attitude towards the continuity of the spiritual gifts can lead to such anomalies. In addition to the test of Scripture and the test of character, history compels us to also include the test of the ecclesial community guided by the Holy Spirit. Any of those involved in such movements must be subordinate to the verification of the church community they to which they belong. Religious extremism has stemmed from individualism and doctrinal chaos.

(5) From the beginning, the focus of the Pentecostal-Charismatic movement was on experience rather than on doctrine. This change of the classical approach has allowed an invasion of practices which seemed unfamiliar to the Conservative Evangelical circles. This explains why Pentecostals' acceptance among Evangelical organizations was done gradually and cautiously. On the other hand, Pentecostalism has promoted ecumenism due to the common experience of the powerful presence of the Holy Spirit in the denominations involved in the ecumenical movement. Experience was considered more important than dogma. Waiting for the "water to get muddy" has made the movement become an adventure with God. As time went by, the universal nature of the movement decreased the predominant role of some gifts. Some statistics show that only half of the Pentecostals and Charismatics today claim 
Emil Bartoş

to have experienced the gift of speaking in tongues. ${ }^{52}$ The spirit is seen as a source of spiritual energy rather than a spiritual advisor who assists the believer or leads them towards truth. The results in the field indicate the direction in which the movement goes. It is not difficult to see that a departure from the revealed Word completely changes the original direction. Also, it is not difficult to notice the fact that the closeness to the revealed Word regulates and normalizes the right direction in which any authentic Christian spiritual movement should go.

52 K. Warrington, "Challenges Facing Pentecostals Today" in: The Journal of the European Pentecostal Theological Association 2 (2011), p. 203. 